\title{
Migration pattern of Gambel's White-crowned Sparrow along the Pacific Flyway
}

\author{
Simeon Lisovski ${ }^{1,2}$. Zoltán Németh $^{1,3} \cdot$ John C. Wingfield ${ }^{1}$. Jesse S. Krause ${ }^{1,4} \cdot$ Keith A. Hobson $^{5}$. \\ Nathaniel E. Seavy ${ }^{6}$. Jennifer Gee ${ }^{7}$. Marilyn Ramenofsky ${ }^{1}$
}

Received: 29 March 2019 / Revised: 3 June 2019 / Accepted: 28 June 2019

(c) Deutsche Ornithologen-Gesellschaft e.V. 2019

\begin{abstract}
White-crowned Sparrow (Zonotrichia leucophrys) populations of western North America exhibit dramatic differences in life history strategies including migration behavior. However, individual migration strategies and population-level migratory patterns remain largely unknown for this species. Here, we focused on the long-distance migratory subspecies, Gambel's White-crowned Sparrow (Zonotrichia leucophrys gambelii). We used ringing, tracking and stable hydrogen isotope $\left(\delta^{2} \mathrm{H}\right)$ analysis of individuals migrating along the Pacific Flyway to assess individual phenology and routes as well as the pattern of connectivity between breeding and non-breeding sites. Results from all three methods, consisting of 79 ring recoveries, four light level geolocator tracks and 388 feather $\delta^{2} \mathrm{H}$ values, indicate low degrees of migratory connectivity. The isotope data provide evidence for leapfrog migration with the more southerly populations traveling greater distances to the breeding grounds than more centrally wintering individuals. Location estimates of four annual journeys revealed individually consistent migration strategies with relatively short flight bouts separated by two to three and two to six stopover sites during spring and autumn migration, respectively. However, combined results from all methods indicate high variability in migration distance among individuals. These findings confirm the phenotypic flexibility observed within this species and highlight the potential of White-crowned Sparrows for further investigations of evolutionary adaptations to ongoing changes in the environment.
\end{abstract}

Keywords Deuterium $\cdot$ Light level geolocation $\cdot$ Passerine migration $\cdot$ Zonotrichia $\cdot$ Leapfrog migration $\cdot$ Migration detours

Communicated by N. Chernetsov.

Simeon Lisovski and Zoltán Németh contributed equally to this work.

Electronic supplementary material The online version of this article (https://doi.org/10.1007/s10336-019-01685-4) contains supplementary material, which is available to authorized users.

Marilyn Ramenofsky

mramenofs@ucdavis.edu

1 Department of Neurobiology, Physiology and Behavior, University of California, Davis, Davis, CA 95616, USA

2 Department of Bird Migration, Swiss Ornithological Institute, Seerose 1, 6204 Sempach, Switzerland

3 Department of Evolutionary Zoology and Human Biology, University of Debrecen, Debrecen 4032, Hungary

4 Department of Biology, University of Nevada, Reno, Nevada 89557, USA
5 Environment and Climate Change Canada, 11 Innovation Boulevard, Saskatoon, SK S7N 3H5, Canada

6 Point Blue Conservation Science, 3820 Cypress Drive, Suite 11, Petaluma, CA 94954, USA

7 James San Jacinto Mountains Reserve, University of California Riverside, University of California Natural Reserve System, PO Box 1775, Idyllwild, CA 92549, USA 


\section{Zusammenfassung}

\section{Zugmuster der Gambel's Dachsammer entlang der Pazifischen Flugroute}

Grundlegende biologische Unterschiede, wie das Zugverhalten, zeichnen die Unterarten der Dachsammer (Zonotrichia leucophrys) im westlichen Nord Amerika aus. Dennoch ist bis heute wenig über individuelle Zugstrategien und populationsspezifische Zugmuster bekannt. Die Gambel`s Dachsammer (Z. leucophrys gambelii) ist die Unterart mit den längsten Zugrouten und steht im Fokus dieser Studie. Unser Ziel war es anhand von Beringungsdaten, Geolokation und der Analyse von Stabiler $\left(\delta^{2} \mathrm{H}\right)$ Isotope, individuelle Zugrouten, das zeitliche Zugverhalten sowie die räumliche Konnektivität zwischen Brut- und Wintergebiet zu charakterisieren. Die Ergebnisse aller drei Methoden, basierend auf 79 Ringfunde, 4 individuellen Zugrouten und $388 \delta^{2} \mathrm{H}$ werten, deuten auf eine niedrige räumliche Konnektivität (migratory connectivity) hin. Die stabile isotope analyse liefert erste Beweise für ein «leapfrog»Zugroutensystem in welchem Individuen aus dem südlicheren Wintergebiet weiter in den Norden ziehen und damit längere Zugrouten haben als Individuen aus dem nördlichen Wintergebiet. Die geschätzten Positionen während des Zuges deuten auf eine hohe Konsistenz innerhalb der vier Individuen, mit relativ kurzen Distanzen zwischen den 2-3 Stopps im Frühjahr und den 2-6 Stopps im Herbst. Alle drei Methoden verdeutlichen jedoch eine hohe inter-individuelle Variation im Zugverhalten. Unsere Ergebnisse bestätigen damit die bekannte phänotypische Flexibilität dieser Art und verdeutlicht das Potential der Dachsammer für weiterführende Untersuchungen zu evolutionären Anpassungen in einer sich verändernden Umgebung.

\section{Introduction}

The White-crowned Sparrow (Zonotrichia leucophrys) has been a focal species of research in North America for over a century. This is, in part, because of dramatic differences in the life histories of the four sub-species of $Z$. leucophrys recognized in western North America, where they have distinct geographic distributions with only narrow zones of sympatry (Blanchard 1941; Dunn et al. 1995). Differences in migratory behavior underpin many aspects of their annual cycle and clearly differentiate subspecies. Originating from a migratory ancestral emberizid species (Winger et al. 2014), Zonotrichia leucophrys nuttalli is currently unique in its sedentary behavior within specific regions of Californian coastal habitat (Chilton et al. 1995). Although all the other subspecies are truly migratory, they vary significantly in their migration distances. Zonotrichia leucophrys pugetensis exhibits the shortest migration (up to $\sim 750 \mathrm{~km}$ ), Zonotrichia leucophrys oriantha migrates intermediate distances (up to $\sim 1500 \mathrm{~km}$ ) and Zonotrichia leucophrys gambelii is a long-distance migrant (up to at least $3500 \mathrm{~km}$ ), which overwinters in the west and southwestern US and into northern Mexico and breeds as far north as the Arctic tundra (Cortopassi and Mewaldt 1965; Morton 2002). This variation in migratory strategies within the White-crowned Sparrow complex demonstrates that phenotypic plasticity in behavior may have caused rapid diversification of its populations (e.g., Cotton 2003; Pulido and Berthold 2004; Yeh and Price 2004; Bearhop et al. 2005; Winkler et al. 2017; Turbek et al. 2018) and ultimately speciation (Irwin and Irwin 2005).

Understanding the behavioral and physiological processes shaping the ecology and evolution of migratory species requires knowledge on patterns of seasonal movements within and across populations. Yet we have only a general understanding of these in many North American model species, including the White-crowned Sparrow. The long-distance migratory subspecies, Gambel's Whitecrowned Sparrow (Z. leucophrys gambelii), is generally on its wintering grounds from October to April, arrives on its breeding grounds in May, and departs towards the end of August or beginning of September (Blanchard and Erickson 1949; Oakeson 1954). In most White-crowned Sparrows, the females tend to winter further south than the males (King et al. 1965) and the spring departure for the breeding grounds is negatively correlated with latitude (King and Mewaldt 1981). Song dialect analysis suggests that wintering flocks tend to have multiple dialects from varying breeding latitudes (DeWolfe and Baptista 1995). With the aim of getting more precise information, thousands of individuals of White-crowned Sparrow subspecies have been individually marked at their breeding, overwintering and stopover sites since 1922 [according to the United States Geological Survey (USGS) Bird Banding Laboratory Database], yet only very few birds have been recovered during this time, and we are still uncertain about their exact paths, timing of departure from both wintering and breeding grounds, migratory connectivity between populations and general migration strategies.

We used an integrated approach consisting of ringing and recovery data and light level geolocation to track individuals, and stable hydrogen isotope $\left(\delta^{2} \mathrm{H}\right)$ analyses from feathers molted at different locations on breeding and wintering sites. We focused on the long-distance migratory subspecies, Gambel's White-crowned Sparrow, along the Pacific Flyway, and specifically aimed to evaluate their migratory patterns, including (1) routes and stopover sites during spring and autumn migration, (2) timing of movements, (3) type of overall migration pattern (e.g., chain or leapfrog migration), 
and (4) degree of migratory connectivity between wintering and breeding locations.

\section{Methods}

Fieldwork was conducted from 2010 to 2014 on the breeding grounds of Z. leucophrys gambelii in Alaska as well as on the wintering grounds in California, and at an autumn stopover site in Central Washington State in 2001 and 2002. Individual birds were captured using mist nets with a playback lure located underneath the net and Potter traps baited with seed. Sex was determined by secondary sexual characteristics during the breeding season and by flattened wing length with a cutoff set to $<74 \mathrm{~mm}$ for females during the nonbreeding season (Fugle and Rothstein 1985; Mewaldt and King 1986).

\section{Ringing data}

Confirmed ring recoveries from Gambel's White-crowned Sparrows were provided by the USGS Bird Banding Laboratory in May 2016. Subspecies can be confidently identified by plumage, beak color and morphology. The dataset was filtered to analyze ringing and recoveries that were recorded west of $105^{\circ} \mathrm{W}$, within the Pacific Flyway, and that contained movements of $>100 \mathrm{~km}$ between initial ringing and ring recovery site, to remove local movements.

\section{Geolocator deployment}

During the spring of 2013 (March-April), light level geolocators (Intigeo P-65; Migrate Technology) were fitted to 20 individuals (14 males with wing length $>76 \mathrm{~mm}$ and six females with wing length $<74 \mathrm{~mm}$ ) caught near the campus of the University of California (UC), Davis $\left(38^{\circ} 33^{\prime} \mathrm{N}\right.$, $\left.121^{\circ} 44^{\prime} \mathrm{W}\right)$. To ensure that only individuals at the study site that winter were tagged, we selected only previously banded adults that had already spent at least one winter at the site. The combined weight of the logger device and the leg harness used to attach the logger to the back of the bird was $1 \mathrm{~g},<4 \%$ of the body mass of $Z$. leucophrys gambelii during winter. Four birds were recaptured and their geolocators removed in the subsequent 2 years. After the final capture, a single tail feather (rectrix R1) was sampled for stable isotope analysis in two of the four birds.

\section{Feather samples}

Gambel's White-crowned Sparrows have two distinct molts per year. The prenuptial (pre-alternate) molt occurs on the wintering grounds prior to departure for spring migration and the postnuptial (pre-basic) molt takes place at the termination of breeding prior to departure for autumn migration. In the latter, all feathers, skin and scales are replaced in adults, typically starting after the nestlings fledge (Morton et al. 1969). During the prenuptial molt, the crown, body feathers, some wing coverts, secondaries 7-9, and the two central rectrices (R1s) or decks are replaced in most birds (Mewald and King 1978). On the breeding sites, we collected unworn central rectrices upon spring arrival or during breeding that were most certainly molted on the wintering grounds. In addition, fifth rectrices (R5) were collected at the end of the postnuptial period in order to obtain estimates of feather $\delta^{2} \mathrm{H}$ values corresponding to local breeding ground conditions. On the wintering grounds in Washington and California, we collected R5s to infer breeding location. Sampling locations included breeding sites in Alaska in the vicinities of Toolik Lake $\left(n_{\text {known }}=44, n_{\text {unknown }}=69 ; 68^{\circ} 38^{\prime} \mathrm{N}\right.$, $\left.149^{\circ} 36^{\prime} \mathrm{W}\right)$ and Fairbanks $\left(n_{\text {known }}=10, n_{\text {unknown }}=28\right.$; $\left.64^{\circ} 51^{\prime} \mathrm{N}, 147^{\circ} 50^{\prime} \mathrm{W}\right)$. On the wintering ranges, feathers were sampled at the Davis, California site $\left(n_{\text {known }}=28\right.$, $n_{\text {unknown }}=79 ; 38^{\circ} 33^{\prime} \mathrm{N}, 121^{\circ} 44^{\prime} \mathrm{W}$ ) and at two southerly overwintering locations in and near the Santa Rosa Mountains, Riverside County, California $\left(n_{\text {known }}=4, n_{\text {unknown }}=18\right.$; Pinyon Flats $\left(33^{\circ} 35^{\prime} \mathrm{N} 116^{\circ} 27^{\prime} \mathrm{W}\right)$ and Deep Canyon Desert Research Station $\left(33^{\circ} 38^{\prime} \mathrm{N} 116^{\circ} 24^{\prime} \mathrm{W}\right)$. During the autumn migration birds were sampled at stopover sites within the Sunnyside Wildlife Recreation Area, Mabton, Washington $\left(n_{\text {unknown }}=96 ; 46^{\circ} 06^{\prime} \mathrm{N} 119^{\circ} 32^{\prime} \mathrm{W}\right)$. We used additional control feathers, with known origin, from Z. leucophrys nuttalli sampled at Bodega Bay, Sonoma County, California $(n=10$; $\left.38^{\circ} 6^{\prime} \mathrm{N}, 123^{\circ} 0^{\prime} \mathrm{W}\right)$ and from $Z$. leucophrys oriantha sampled at Sonora pass, Tuolumne County, California $(n=12$; $\left.38^{\circ} 18^{\prime} \mathrm{N}, 119^{\circ} 30^{\prime} \mathrm{W}\right)$. See Supplementary material (S1) for a detailed overview of feather samples.

\section{Solar geolocation}

Raw light level recordings were used to infer migration trajectories. First, twilight times were detected using the $\mathrm{R}$ package TwGeos (Lisovski et al. 2015). We chose a light level threshold of $1.5 \mathrm{~lx}$ and used this value to automatically determine all sunrises and sunsets (hereafter "twilight events"). Highly erroneous twilight events, for example due to heavy shading, were automatically adjusted using the twilighAdjust function (with $60 \mathrm{~min}$ as cut-off for outliers and $30 \mathrm{~min}$ as excepted variability for adjacent twilight events). For each individual, one to three twilight events were subject to this adjustment procedure. Next, the annotated light data were used to estimate the migration path using the R package FLightR (Rakhimberdiev et al. 2017). For calibration, we used the periods from 1 April 2013, after tag attachment, until 18 April 2013, as well as the period (2-3 weeks) 
before a tag was retrieved and after the birds returned to their wintering site in Davis, California. Location estimates were spatially constrained to the areas between $170^{\circ} \mathrm{W}-100^{\circ} \mathrm{E}$ and $30^{\circ}-70^{\circ} \mathrm{N}$ as well as to terrestrial land (with a $50-\mathrm{km}$ buffer zone into the ocean). The maximum flight distance between two consecutive twilights was limited to $1500 \mathrm{~km}$. Finally, we optimized the movement model with 1 million particles and with automatic outlier exclusion. We used the median location for each twilight time (based on the generated location's posterior probability distribution of $1 \times 10^{6}$ particles per twilight) to visualize the migration route. We also separated periods of residency (stopover locations) from periods of active flight using the FLightR function stationary.migration.summary. Breeding sites were defined as relatively stable location estimates before or after the individual experienced 24-h daylight. Raw data, twilight annotations and detailed processing script were uploaded onto movebank (http://www.movebank.org; Study name: Gambel's Whitecrowned Sparrow migratory routes.

\section{$\delta^{2} \mathrm{H}$ analyses}

Feather samples were analyzed at the UC Davis Stable Isotope Facility $(n=286)$ and the National Hydrology Research Centre (NHRC) in Saskatoon, Canada $(n=110)$. See Supplementary material S1 for more detailed information on isotopic methods. Feather $\delta^{2} \mathrm{H}$ analyses can only be compared among laboratories if the $\delta^{2} \mathrm{H}$ value of the non-exchangeable $\mathrm{H}$ portion is reported. This is due to the fact that $\mathrm{H}$ can exchange between ambient water vapor in the laboratory and $\mathrm{H}$ in feather keratins (MeierAugenstein et al. 2013). We thus ensured that both laboratories calibrated their feather $\delta^{2} \mathrm{H}$ values using the same keratin reference materials, as reported below, and that feathers and standards were prepared at the same facility. At each laboratory, feathers were allowed to equilibrate with ambient vapor for at least $96 \mathrm{~h}$. Feather samples were prepared in the Environment Canada Stable Isotope Laboratory of the NHRC. Each feather sample was soaked for $5 \mathrm{~h}$ in 2:1 chloroform: methanol solution then rinsed and dried in a fume hood for $48 \mathrm{~h}$. The impact of exchangeable hydrogen on isotopic measurements was corrected using the comparative equilibration method (Wassenaar and Hobson 2003). Within analytical runs, we used the Environment Canada keratin reference standards Caribou hoof (CBS; - 197\%o) and kudu horn (KHS; - 54.1\%o) to account for exchangeable $\mathrm{H}$ and to calibrate samples. At NHRC, $\delta^{2} \mathrm{H}$ measurements were performed on $\mathrm{H}_{2}$ gas derived from high-temperature $\left(1350{ }^{\circ} \mathrm{C}\right)$ flash pyrolysis on glassy carbon of $350 \pm 10 \mu \mathrm{g}$ of distal-vane feather subsamples in crushed silver capsules. Resulting $\mathrm{H}_{2}$ gas was separated in a Eurovector 3000 (Milan, Italy) elemental analyzer and introduced into an Isoprime (Crewe, UK) continuous-flow isotope-ratio mass spectrometer. All results are reported for non-exchangeable $\mathrm{H}$ expressed in the typical $\delta$ notation, in units per mil (\%o), and normalized on the Vienna Standard Mean Ocean Water-Standard Light Antarctic Precipitation standard scale (Wassenaar and Hobson 2006). Based on within-run replicate $(n=5)$ measurements of laboratory keratin standards, we estimated measurement precision to be $\pm 2 \%$. At the UC Davis laboratory, feathers were similarly treated with a 2:1 chloroform:methanol solvent. Feather vane was sampled and $1.25 \mathrm{mg} \pm 0.05 \mathrm{mg}$ transferred to silver capsules. Samples were analyzed for $\delta^{2} \mathrm{H}$ using an Elementar PyroCube (Elementar Analysensysteme, Hanau, Germany) interfaced with an Isoprime VisION (Isoprime, Stockport, UK) mass spectrometer. Samples were combusted to $\mathrm{H}_{2}$ in a glassy carbon reactor at $1450{ }^{\circ} \mathrm{C}$. During analysis, samples were interspersed with several replicates of at least four different laboratory reference materials. These laboratory reference materials had been previously calibrated against international reference materials, including IAEA-CH7, USGS-42, USGS-43, CBS and KHS. Final feather $\delta^{2} \mathrm{H}$ values were calibrated against the CBS and KHS standards as with the Environment Canada laboratory.

\section{Spatial assignment}

To assign each feather to a geographical region, we downloaded the $\delta^{2} \mathrm{H}$ in precipitation $\left(\delta^{2} \mathrm{H}_{\mathrm{P}}\right)$ isoscape for North America using IsoMap, an online resource that allows user to create region- and time-specific maps (Bowen et al. 2014). We created a long-term (amount-weighted mean annual) $\delta^{2} \mathrm{H}_{\mathrm{P}}$ isoscape across all months and from 1970 to 2006 (IsoMap job key: 57953). The precipitation model was further modified using Climatic Research Unit-derived independent variables (altitude, latitude and longitude). To convert the $\delta^{2} \mathrm{H}_{\mathrm{P}}$ isoscape to a Gambel's White-crowned Sparrowspecific feather $\left(\delta^{2} \mathrm{H}_{\mathrm{f}}\right)$ isoscape, we used $\delta^{2} \mathrm{H}_{\mathrm{f}}$ values from feathers molted at known location (see Supplementary material S2) and applied a polynomial correlation incorporating potential regional variation in isotopic discrimination by sampling (iter $=1000$ ) from the $\delta^{2} \mathrm{H}_{\mathrm{P}}$ isoscape within $50 \mathrm{~km}$ of the feather sampling location. The mean intercept and slope were then used to then convert $\delta^{2} \mathrm{H}_{\mathrm{P}}$ to $\delta^{2} \mathrm{H}_{\mathrm{f}}$.

\section{Statistical analyses}

The potential influences of sex and age on $\delta^{2} \mathrm{H}_{\mathrm{f}}$ were tested using a linear modeling approach in R (Team 2014) controlling for sampling location. 


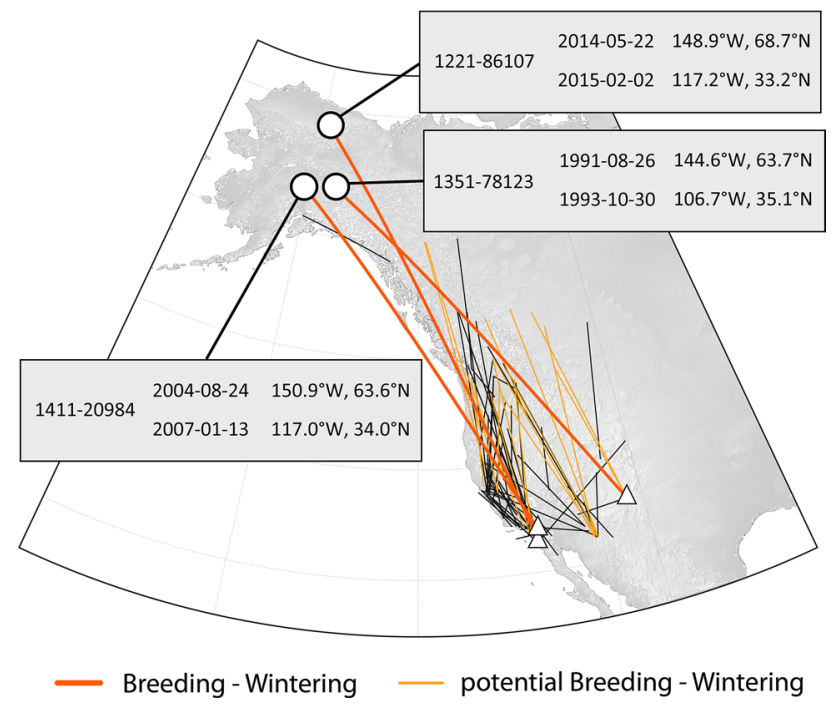

Fig. 1 Confirmed ringing and recovery data with distances $>100 \mathrm{~km}$ for Gambel's White-crowned Sparrow (Zonotrichia leucophrys gambelii) along the Pacific Flyway (west of $105^{\circ} \mathrm{W}$ ). Thick orange lines indicate individual connections between birds banded and recovered during the breeding period and wintering period. Thin yellow lines may also show such connections but the dates of either ringing or recovery fall into migration periods and we are thus not entirely confident that they represent both. For the black lines, both ringing and recovery is within the breeding or wintering period or at the very beginning or end of the migration periods (US Bird Banding Laboratory data). The boxes show individual ID, ringing and recovery date and location (colour figure online)

\section{Results}

\section{Ringing data}

The filtered ringing dataset contained 79 recoveries for Gambel's White-crowned Sparrows. For most (58) of these recoveries, little information could be inferred about the link between breeding and non-breeding site, e.g., migratory connectivity, because at least one of the captures occurred during the migration period. There were 18 recoveries that potentially link breeding and wintering sites but were not definitive because at least one of the captures occurred on the cusp of the migration period. One of these birds was recaptured north of $45^{\circ}$, indicating that it had potentially reached its breeding site. Only three of the recoveries provided definitive evidence of connections between wintering and breeding periods (Fig. 1).

\section{Solar geolocation}

All four individuals that were successfully tracked migrated to their breeding sites in Alaska (Fig. 2). Except for one female (ID541), all of the individuals were males. Three individuals were found to have bred relatively close together (within approximately $250-500 \mathrm{~km}$ ) south of the Brooks Range and just west of the US and Canadian border. One male (ID4552) migrated to far southwestern Alaska. Except for ID4541, location estimates for breeding sites were similar before and after the 24-h period for which locations could not be estimated. However, due to the small and slow change in light intensity over the day, accuracy and precision in location estimates are generally low and variation in location estimates is large. Thus, location estimates that may indicate movements within the breeding site (e.g., ID4543) cannot be disentangled from error. All four individuals departed the Davis wintering site within 20 days of each other (7-27 April). The duration of travel greatly varied ( 22-46 days and mean of 32 days) as did the date of arrival of birds at their respective breeding sites (4 May-4 June). During the spring migration, individuals had two to three major stopover periods lasting $1-12$ days ( $m e a n=6.3$ days). The spring migration routes roughly followed the shortest distance route (over land) between the wintering and breeding sites, north through the Central Valley of California and the Cascade Mountain range then along the Rocky Mountains. The individual that migrated to southwestern Alaska (ID4552) seemed to have followed coastal areas from about $55^{\circ} \mathrm{N}$. The total spring migration distance ranged from 3280 to $4300 \mathrm{~km}$. Birds resided between 82 and 122 days on their breeding grounds and departed between 25 August and 3 September. Interestingly, all easterly breeding individuals departed on the same day (3 September). As in spring, the duration of the autumn migration was highly variable across individuals. Autumn travel lasted between 24 and 63 days with an average of 43.5 days. The number of major stopovers per individual ranged from two to six and lasted 2-9 days. In contrast to the spring migration, during the autumn migration individuals deviated from the shortest land route by taking a pronounced eastern leg initially. All individuals, and even ID4552 traveling from far western Alaska, first migrated east to approximately $125^{\circ} \mathrm{W}$. From there, individuals turned south following the eastern slope of the Rocky Mountains until crossing the mountain ranges of a larger area of the US and Canadian border and headed south along the Cascade and Sierra Nevada Mountain ranges to the Central Valley of California. Arrival dates at the wintering site in Davis ranged between 27 September and 19 October. Total migration distances during the autumn migration ranged from 3592 to $4666 \mathrm{~km}$, and round trips between 6872 and $8966 \mathrm{~km}$ (Table 1).

\section{Stable isotope analysis}

Values of $\delta^{2} \mathrm{H}_{\mathrm{f}}$ in feathers of $Z$. leucophrys gambelii molted on the wintering grounds were found to be 

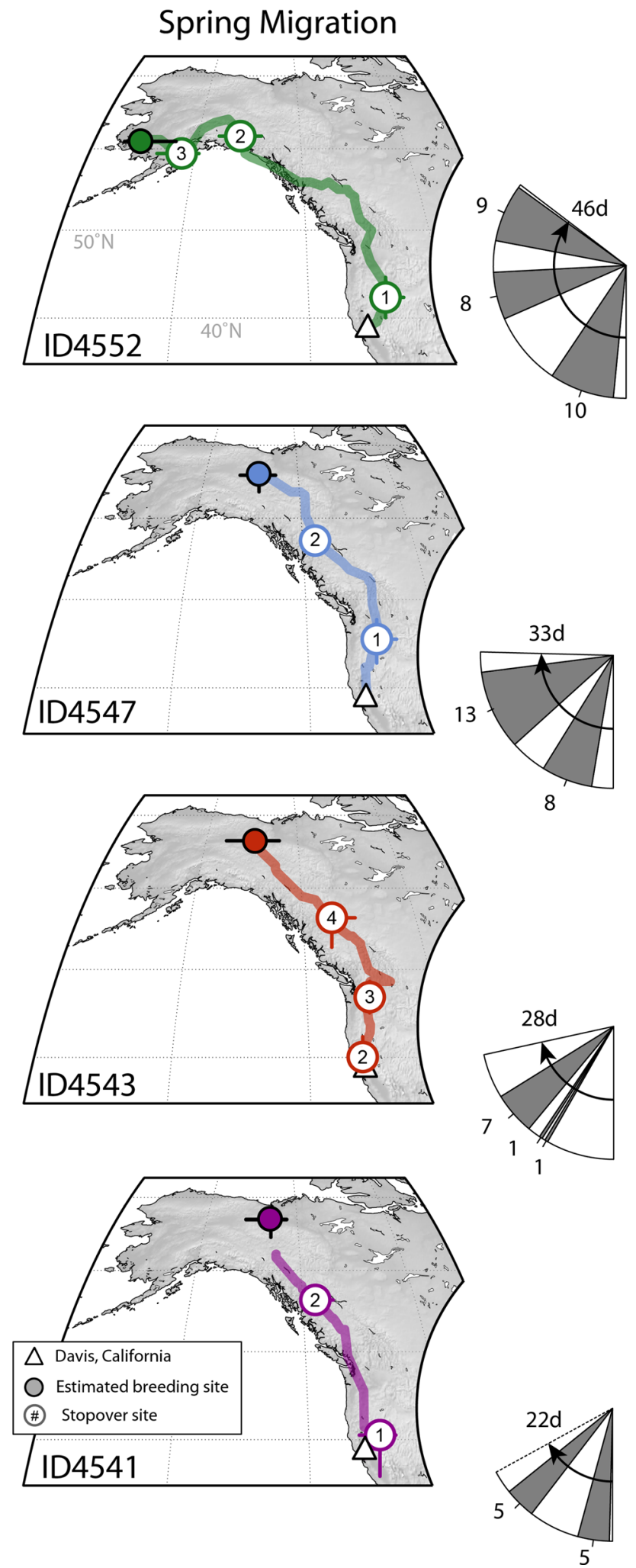

Fig. 2 Individual migration routes of four Gambel's White-crowned Sparrows (Z. leucophrys gambelii) along the Pacific Flyway. Migration routes were separated by spring (left panels) and autumn (right panels) migration. Colored lines on each map indicate median track of the location estimates. Sequentially numbered circles indicate identifiable stopover sites $(95 \% \mathrm{CI})$ that were visited for more than

\section{Fall Migration}
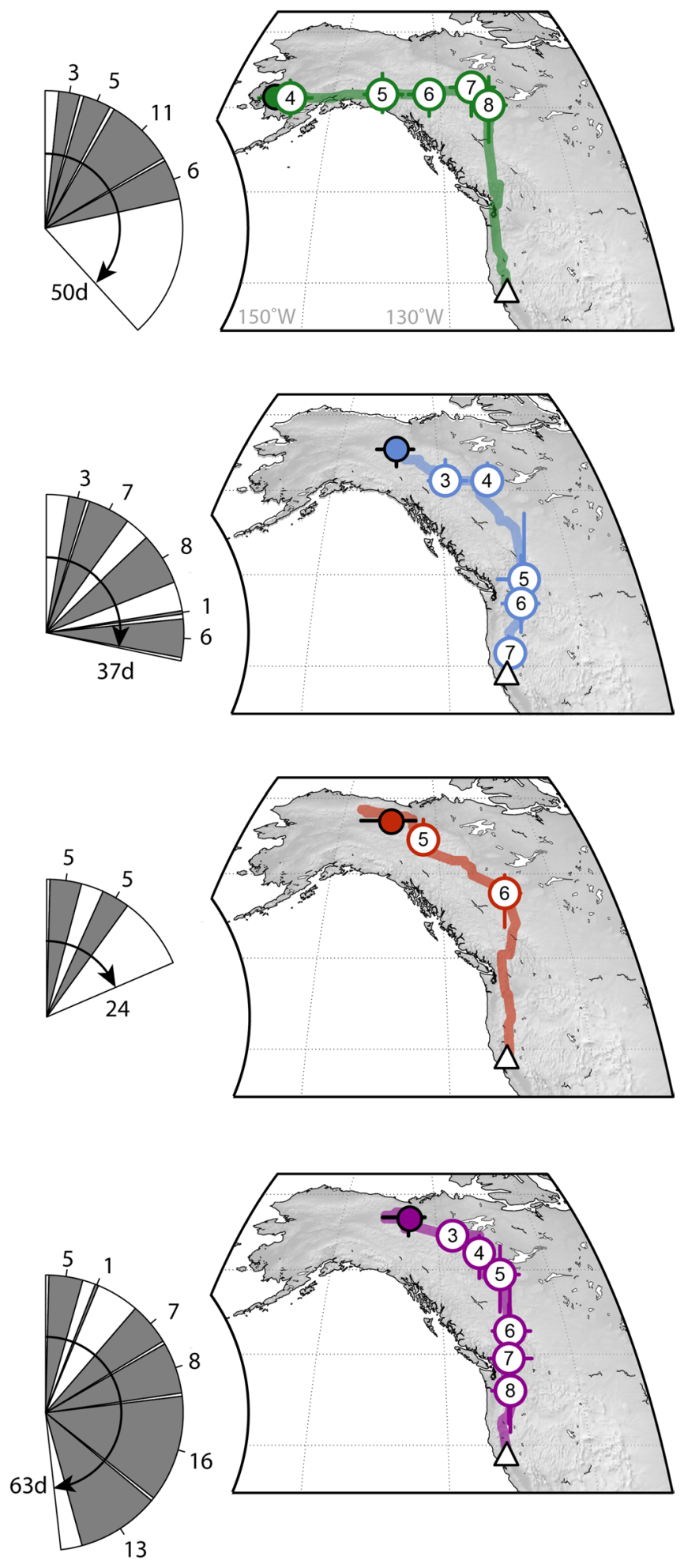

1 day $(d)$, e.g., two twilight times. Each track starts and ends either at Davis (triangle) or at the estimated breeding site (rectangle). Pie charts in the center of each individual migration track show the approximate number of days spent at each stopover site (gray), and duration of each leg of the migration (white) during spring (left) and autumn (right) stages 
Table 1 Individual migration schedules (2013)

\begin{tabular}{|c|c|c|c|c|c|c|c|}
\hline & Departure & Stopovers & Arrival & & Departure & Stopovers & Arrival \\
\hline ID4552 & 20 April & 3 & 4 June & Breeding & 25 August & 4 & 11 October \\
\hline ID4547 & 20 April & 2 & 24 May & & 3 September & 5 & 07 October \\
\hline ID4543 & 7 April & 3 & 4 May & & 3 September & 2 & 27 September \\
\hline ID4541 & 27 April & $\geq 2$ & 19 May & & 3 September & 6 & 19 October \\
\hline
\end{tabular}

independent of age (controlled for sampling location: $\left.t_{2,95}=0.32, p=0.748\right)$, but were significantly affected by sex $\left(\Delta \delta^{2} \mathrm{H}_{\mathrm{f}}=11.4 \% o, t_{1,80}=2.90, p=0.004\right)$. Values of $\delta^{2} \mathrm{H}_{\mathrm{f}}$ of winter-grown feathers of females from Toolik Lake, and Fairbanks, were significantly higher than those of males (Fig. 3), indicating more southern wintering grounds. In contrast, $\delta^{2} \mathrm{H}_{\mathrm{f}}$ values of feathers molted at the breeding grounds were independent of sex (controlled for sampling location: $t_{1,95}=1.74, p=0.083$ ). Mean $\delta^{2} \mathrm{H}_{\mathrm{f}}$ of all feathers molted on the breeding grounds was $-143.0 \%$ o ( -178.0 to $-70.5 \%$ ), whereas for feathers molted on the wintering grounds it was $-90.2 \%$ o $(-132.0$ to $-33.0 \%$ ). $\delta^{2} \mathrm{H}$ in tail feathers that were grown on the breeding grounds and sampled on the wintering grounds showed a trend with latitude with lowest values observed in the south, from a seemingly female-biased population (85.7\% females in 30 trapped individuals) in the Santa Rosa Mountains ( $-161.22 \% \circ \pm 8.9$ SD), intermediate values in Davis $(-146.91 \% \circ \pm 13.3 \mathrm{SD})$, and highest values in Sunnyside $(-136.46 \% \circ \pm 18.96 \mathrm{SD})$, with all differences being significant $(p<0.001)$.

\section{Discussion}

Our results suggest relatively weak migratory connectivity for Gambel's White-crowned Sparrows along the Pacific Flyway, but provide evidence for leapfrog and clockwise seasonal loop migration during which the birds circumnavigate the Rocky Mountain chain in the Yukon Territories and possibly take advantage of seasonal resources and advantageous climatic conditions. Duration of the spring and autumn bouts did not vary to any great extent except that the number of stopovers in autumn exceeded those in spring.

During the initial period of spring migration, and on their way to their breeding site in Alaska, all four successfully tracked individuals headed north, presumably moving within the Central Valley. The central-north Alaska breeding birds continued on their great circle route to their breeding sites while the westerly breeding individual (ID4552) turned westwards to the coast at about $54^{\circ} \mathrm{N}$. This latter individual resumed migration on a coastal route, similar to that found in closely related Golden-crowned Sparrows (Zonotrichia atricapilla) wintering in coastal regions of California and breeding in similar areas in southwestern Alaska (Seavy et al. 2012; Rakhimberdiev et al. 2015; Cormier et al. 2016). After showing a similar direction and strategy in the early phase of migration, with at least one stopover (for 4-6 days) in the Central Valley of California, the strategies became very different after the birds potentially headed for higher elevations of the Rocky Mountains and on their continuing flight towards their breeding sites (Fig. 2). Surprisingly, and in contrast to the small deviation from the great circle route in spring, all individuals made an eastern diversion during the autumn migration, before heading south towards their wintering sites, which suggested a clockwise loop migration. Although speculative, this diversion, which is considerably larger for the westerly breeding individual, may follow a historic route for the species, or indicate that they track a more predictable food resource to the east during the autumn months. The migration route of a Golden-crowned Sparrow that bred in coastal Alaska exhibited a similar eastward path during the autumn compared to a more westerly path during the spring (Rakhimberdiev et al. 2015). Once moving south along the eastern slope of the Rocky Mountains, all birds showed a greater number of stopovers than during the spring stage, which may also suggest a greater variability of available resources along this route. In support of this, Boyle and Martin (2015) noted greater aggregations of autumn migrants in alpine, subalpine and montane forests of western British Colombia, Canada than at lower elevations, which suggested locations of plentiful resources. Wind and weather patterns may also be more favorable along the eastern slopes of the Rocky Mountains during autumn (Horton et al. 2016).

Departure dates from the wintering site were similar among individuals (mid/end April) and independent of their destination. This similarity was even higher at departure from the breeding site in late summer. After the relatively short and compressed breeding period of 2.5 months that entails territorial establishment, onset and completion of breeding, fledging of young, postnuptial molt and preparation for autumn departure (Farner and Wingfield 1978), individuals left their breeding areas within a short window of 9 days. In fact, all north-central breeding individuals left the breeding site within 1-3 days, given the inaccuracies of location, potentially utilizing advantageous weather conditions (e.g., Schmaljohann and Naef-Daenzer 2011) or possibly escaping poor conditions on the breeding grounds. In terms of migration speed, and to our surprise, we found no support for a longer autumn migration period in comparison with 
Fig. 3 a Hydrogen stable isotope values of feathers $\left(\delta^{2} \mathrm{H}_{\text {feather }}, \delta^{2} \mathrm{H}_{F}\right)$. of unknown origin sampled during the breeding period at Toolik Lake and Fairbanks, Alaska $(A K)$ and during the non-breeding period (b) at Sunnyside, Washington (WA), Davis and Rosa Mountains, California $(C A)$. Color scale of the maps shows the potential spatial distribution of ${ }^{2} \mathrm{H}$ levels of feathers of Gambel's White-crowned Sparrows within the range of the sampled feathers and based on a precipitation model that accounted for altitude, minimum temperature, longitude and latitudinal variation. Gray area indicates locations with $>1$ month snow cover during the year (Robinson et al. 2012) and thus unlikely locations for non-breeding Gambel's White-crowned Sparrows. $\delta^{2} \mathrm{H}$ of individual feather samples are shown in the scatterplots separated by location and colored using the same color scale as shown in the maps. The two samples (ID4543, ID4552) highlighted in b indicate the respective individuals of the geolocator analysis. a Boxplots indicate the significantly different $\delta^{2} \mathrm{H}$ signatures between females (gray) and males (white) at the wintering sites (colour figure online)

the spring one, as reported by Nilsson et al. (2013). Optimal migration theory predicts that long-distance migrants use a time-minimizing strategy-migrating as fast as possible_-during spring to ensure timely arrival (Alerstam 1990; McNamara et al. 1998) that is often associated with higher reproductive success (Kokko 1999; Smith and Moore 2005). On the other hand, autumn migration is expected to be less time constrained (Piersma and Drent 2003) because it is generally assumed that a timely arrival at the wintering grounds has fewer fitness consequences (McNamara et al. 1998), and it is thus advantageous to minimize energy costs-reducing fuel loads by stopping more frequently to feed and restduring autumn migration (Hedenstrom and Alerstam 1997). While our sample size is small, and more tracks are needed to confirm this pattern, environmental conditions at the breeding sites and along the migratory route may explain this phenomenon. The costs associated with an early spring arrival may vary by latitude and altitude of breeding habitats (Kokko 1999; Morton 2002). Namely, the costs might be different for birds breeding in temperate latitudes at lower elevations that experience more predictable conditions during spring compared to those breeding in the Arctic or at elevations where extreme and unpredictable weather events frequently occur during the early season impacting resource availability (e.g., Pielou 1994) and survival (Oakeson 1954). It has been shown that White-crowned Sparrows avoid settling on breeding sites under severe conditions, i.e., heavy snow cover at both high latitudes and altitudes (Morton 2002; Hahn et al. 2004; Wingfield et al. 2007; Boelman et al. 2016; Krause et al. 2018). Additionally, while food resources upon arrival in temperate environments may vary to a certain extent between years, snow cover due to snowstorms and freezing temperatures may reduce the availability of food and cover, posing a real challenge to birds arriving early in the Arctic. The slower progression of the spring migration of Arctic breeders compared to many temperate breeding songbirds (reviewed in Nilsson et al. 2013) may indicate that birds use environmental conditions along the route to
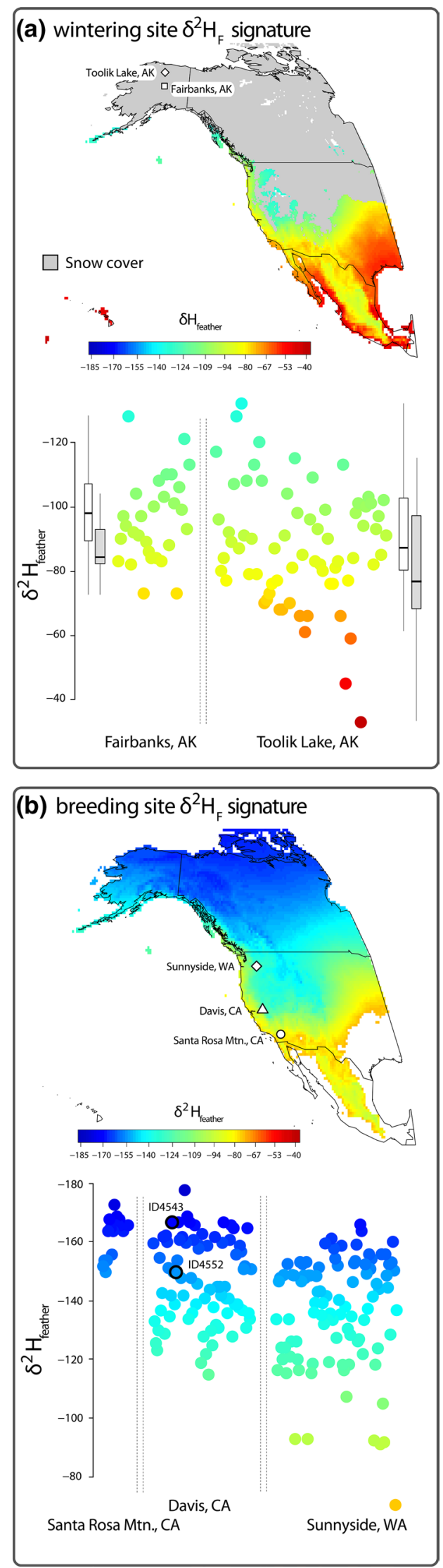
synchronize movements and time their northward progression (Tottrup et al. 2008; Nuijten et al. 2014; Schmaljohann et al. 2017). Thus, selection may favor energy-minimizing strategies during both migration bouts in Arctic breeding songbirds. This may also explain the fast and long migration leg of ID4552 from the Central Valley to the coast of Southwest Alaska in spring. Coastal regions are known to be more predictable due to the temperature buffering effect of the ocean, and spring starts earlier. Yet, this individual had three longer stopovers in Alaska before proceeding to its breeding area. A similar pattern has been observed for Golden-crowned Sparrows: individuals migrating northwards along the coast to coastal breeding sites moved faster than individuals migrating to interior breeding sites (Cormier et al. 2016).

Our stable isotope analysis and the few available band recoveries provided further evidence that birds sampled within relatively small areas across the wintering distribution were derived from individuals distributed across the entire breeding range (Fig. 3). This pattern was reinforced by the tracking data, as three individuals headed towards central-north Alaska and ended up relatively close together, but one migrated to the southwestern coastal region about $1500 \mathrm{~km}$ distant from the others. These three lines of evidence indicate relatively few connections between breeding and wintering populations, and thus a low degree of migratory connectivity (Boulet and Norris 2006; Bauer et al. 2016). Similarly, feathers that were molted during the winter but sampled on the breeding grounds at two locations in central-north Alaska had $\delta^{2} \mathrm{H}_{\mathrm{f}}$ values that were expected from across the wintering range. Extreme values even indicate potential wintering sites as far south as northern Mexico. At the other extreme, very low $\delta^{2} \mathrm{H}_{\mathrm{f}}$ values measured in feathers from birds caught in Washington indicating a breeding site just south of Canada. Yet, we have to be careful when interpreting these extreme values, since they might be outliers, which can be the result of the general problem of including mountainous areas in modeling isoscapes, or the result of micro-habitat effects that do not reflect the large-scale modeling result of the maps shown in Fig. 3. Some uncertainties may also result from feathers that were molted outside the regular molting period and the resulting misinterpretation of their origin. However, even if we ignore the extreme values and remain aware of our low sample size, all the data pooled together suggest a leapfrog migration with more southerly wintering groups traveling greater distances to more northerly breeding grounds than more centrally based groups. The very low $\delta^{2} \mathrm{H}_{\mathrm{f}}$ values in feathers of individuals from the most southern sites in California indicate that they were exclusively long-distance migrants. Birds wintering in the intermediate location in Davis show a higher degree of variation with individuals that may breed along the southern coast of Canada, whereas some individuals caught in Washington
State might indeed be year-round residents, as suggested by the annual Christmas counts, or perform only very short and potentially altitudinal migration, similar to that of the closely related and sympatric Puget Sound White-crowned Sparrow (Z. leucophrys pugetensis) (Hunn and Beaudette 2014). This leapfrog migration was consistent across our latitudinal sampling locations and may be exhibited by other species along this flyway (DeWolfe and Baptista 1995; Bell 1997; but see Fraser et al. 2018). In addition, a detailed analysis of $\delta^{2} H_{f}$ values sampled at the wintering sites also revealed a modest but significant difference between sex classes with females wintering further south. Latitudinal sex differences in the overwintering site is a well-documented pattern in many north temperate migratory species (Ketterson and Nolan 1976). One of the many drivers for this could be that females of smaller body size do not compete well with larger males, and thus tend to migrate further south to avoid competition for resources in winter. This differential could create a geographic separation of sex and sometimes age classes during winter months (Terrill and Ohmart 1984; Terrill 1987; see also Cristol et al. 1999).

The variation in migratory strategies even within the gambelii subspecies suggested by this paper reflects the phenotypic flexibility expressed within the Pacific Whitecrowned Sparrow complex, and again indicates potentially rapid changes in behavior and physiology (King and Farner 1963; Farner and Wingfield 1978; Morton 2002). While our data are inconclusive and we encourage further investigations, taken together with the initial evidence that some Gambel's White-crowned Sparrows breed as far south as the Cascade Mountains of Washington State (Hunn and Beaudette 2014), we can speculate that wintering and breeding ranges of these birds may even overlap in southwestern Canada and northwestern US. There could thus be a continuous gradient of migratory strategies within Gambel's White-crowned Sparrows with individuals that winter and breed within or close to the potential overlapping region being more like the short-distance migrating Puget Sound subspecies than the Gambel's White-crowned Sparrows that winter further south.

Acknowledgments We thank Shallin Busch, Emilie Graves, Eunice Jiang, Samarah Raouf and Jake Schas for support in the field and Phil Mattocks for information on the wintering populations of Whitecrowned Sparrows in Washington State. Angelina Nefedova's precise measurements of feather samples were critical for the preparation of the isotope measurements. We thank Joy Matthews and Irene Yen at the UC Davis Stable Isotope Facility for their kind assistance during the stable isotope analysis. We are grateful to Michael Hallworth for exploring different stable isotope assignment approaches. Two anonymous reviewers provided comments on an earlier draft of the manuscript. Support for the project was provided by the National Science Foundation IOS no. 0920791 and ARC no. 1147289 to M. R. and A. R. C. (no. 0909133) and the Endowed Chair in Physiology from the UC Davis to J. C. W. Both M. R. and J. C. W. were supported by the Thinker-in-Residence Program, Deakin University, Waurn Ponds, 
Australia. Z. N. was supported by the National Research, Development and Innovation Office of Hungary (NKFIH PD 121013, FK 124414) during the preparation of the manuscript.

Author contributions Z. N., M. R. and J. C. W. initiated the research; Z. N., M. R., J. G., J. S. K. and K. A. H. collected data and performed lab analysis; S. L. analyzed the data with support from N. E. S.; S. L. and M. R. wrote the manuscript with contributions from all authors.

\section{Compliance with ethical standards}

Ethics All procedures and animal handling were done in accordance with the regulations of the University of Washington and UC Davis Institutional Animal Care and Use Committees (protocols nos. 2644 and 17144 , respectively) and conducted under the scientific collecting permits issued by the California Department of Fish and Wildlife (no. 11024) and US Fish and Wildlife Department (no. MB11826A).

\section{References}

Alerstam T (1990) Bird migration. Cambridge University Press, Cambridge

Bauer S, Lisovski S, Hahn S (2016) Timing is crucial for consequences of migratory connectivity. Oikos 125:605-612. https:// doi.org/10.1111/oik.02706

Bearhop S, Fiedler W, Furness RW et al (2005) Assortative mating as a mechanism for rapid evolution of a migratory divide. Science 310:502-504. https://doi.org/10.1126/science.1115661

Bell CP (1997) Leapfrog migration in the fox sparrow: minimizing the cost of spring migration. Condor 99:470-477. https://doi. org/10.2307/1369953

Blanchard F (1941) The White-crowned Sparrows (Zonotrichia leucophrys) of the Pacific Seaboard: environment and annual cycle. University of California Press, Berkeley

Blanchard BD, Erickson MM (1949) The cycle of the Gambel Sparrow. University of California Press, Berkeley

Boelman NT, Holbrook JD, Greaves HE et al (2016) Airborne laser scanning and spectral remote sensing give a bird's eye perspective on arctic tundra breeding habitat at multiple spatial scales. Remote Sens Environ 184:337-349. https://doi.org/10.1016/j. rse.2016.07.012

Boulet M, Norris DR (2006) The past and present of migratory connectivity. Ornithological Monogr 61:1-13

Bowen GJ, Liu Z, Vander Zanden HB et al (2014) Geographic assignment with stable isotopes in IsoMAP. Methods Ecol Evol 5:201-206

Boyle WA, Martin K (2015) The conservation value of high elevation habitats to North American migrant birds. Biol Conserv. https ://doi.org/10.1016/j.biocon.2015.10.008

Chilton G, Baker MC, Barrentine CD, Cunningham MA (1995) White-crowned Sparrow (Zonotrichia leucophrys). Cornell Lab of Ornithology, Ithaca

Cormier RL, Humple DL, Gardali T, Seavy NE (2016) Migratory connectivity of Golden-crowned Sparrows from two wintering regions in California. Anim Migr 3:48-56

Cortopassi AJ, Mewaldt LR (1965) The circumannual distribution of White-crowned Sparrow. Bird Band 36:41-169

Cotton PA (2003) Avian migration phenology and global climate change. Proc Natl Acad Sci USA 100:12219-12222. https://doi. org/10.1073/Pnas.1930548100
Cristol DA, Baker MB, Carbone C (1999) Differential migration revisited. In: Nolan V, Ketterson ED, Thompson CF (eds) Current ornithology. Springer, Boston

DeWolfe BB, Baptista LF (1995) Singing behavior, song types on their wintering grounds and the question of leapfrog migration in Puget Sound White-crowned Sparrows. Condor 97:376-389

Dunn JL, Garret KL, Alderfer JK (1995) White-crowned Sparrow subspecies: identification and distribution. Birding 27:182-200

Farner DS, Wingfield JC (1978) Environmental endocrinology and the control of annual reproductive cycles in passerine birds. In: Assenmacher I, Farner DS (eds) Environmental endocrinology. Springer, New York, p 44

Fraser KC, Roberto-Charron A, Cousens B et al (2018) Classic pattern of leapfrog migration in Sooty Fox Sparrow (Passerella iliaca unalaschkensis) is not supported by direct migration tracking of individual birds. Auk 135:572-582. https://doi. org/10.1642/AUK-17-224.1

Fugle GN, Rothstein SI (1985) Age-related variation in size and crown plulmage brightness in wintering white-crowned sparrows. J Field Ornithol 56(4):356-368

Hahn TP, Sockman KW, Breuner CW, Morton ML (2004) Facultative altitudinal movements by mountain White-crowned Sparrows, Zonotrichia leucophrys oriantha, in the Sierra Nevada. Auk 121:1269-1281

Hedenstrom A, Alerstam T (1997) Optimum fuel loads in migratory birds: distinguishing between time and energy minimization. J Theor Biol 7:227-234

Horton KG, Van Doren BM, Stepanian PM et al (2016) Seasonal differences in landbird migration strategies. Auk 133:761-769. https://doi.org/10.1642/Auk-16-105.1

Hunn ES, Beaudette D (2014) Apparent sympatry of two subspecies of the White-crowned Sparrow, Zonotrichia leucophrys pugetensis and gambelii, in Washington State. West Birds 45:132-140

Irwin DE, Irwin JH (2005) Siberian migratory divides: the role of seasonal migration and speciation. In: Greenberg R, Marra PP (eds) Birds of two worlds: the ecology and evolution of migration. Johns Hopkins University Press, Baltimore

Ketterson ED, Nolan V (1976) Geographic variation and its climatic correlates in sex-ratio of Eastern-wintering Dark-eyed Juncos (Junco hyemalis hyemalis). Ecology 57:679-693. https://doi. org/10.2307/1936182

King JR, Farner DS (1963) The relationship of fat deposition to Zugunruhe and migration. Ann N Y Acad Sci 131:422-440

King JR, Mewaldt LR (1981) Variation of body weight in Gambel's White-crowned Sparrows in winter and spring: latitudinal and photoperiodic correlates. Auk 98:752-764

King JR, Farner DS, Mewaldt LR (1965) Seasonal sex and age ratios in populations of the White-crowned Sparrows of the race gambelii. Condor 67:489-504. https://doi.org/10.2307/1365613

Kokko H (1999) Competition for early arrival in migratory birds. J Anim Ecol 68:940-950. https://doi.org/10.104 6/J.1365-2656.1999.00343.X

Krause JS, Pérez JH, Chmura HE et al (2018) Weathering the storm: do arctic blizzards cause repeatable changes in stress physiology and body condition in breeding songbirds? Gen Comp Endocrinol 267:183-192. https://doi.org/10.1016/J.YGCEN.2018.07.004

Lisovski S, Sumner MD, Wotherspoon SJ (2015) TwGeos: Basic data processing for light based geolocation archival tags. https://rdrr. io/github/slisovski/TwGeos/

McNamara JM, Welham RK, Houston AI (1998) The timing of migration within the context of an annual routine. J Avian Biol 29:416423. https://doi.org/10.2307/3677160

Meier-Augenstein W, Hobson KA, Wassenaar LI (2013) Critique: measuring hydrogen stable isotope abundance of proteins to infer origins of wildlife, food and people. Bioanalysis 5:751-767 
Mewaldt LK, King JR (1978) Latitudinal variation in prenuptial molt in wintering Gamel's White-crowned Sparrows. N Am Bird Bander 3:138-144

Mewaldt LR, King JR (1986) Estimation of sex ratio from wing-length in birds when sexes differ in size but not coloration. J Field Ornithol 57:155-167

Morton ML (2002) The mountain white-crowned sparrow: migration and reproduction at high altitude. Stud Avian Biol 24:1-236

Morton ML, King JR, Farner DS (1969) Postnuptial and postjuvenal molt in White-crowned Sparrows in Central Alaska. Condor 71:376. https://doi.org/10.2307/1365736

Nilsson C, Klaassen RHG, Alerstam T (2013) Differences in speed and duration of bird migration between spring and autumn. Am Nat 181:837-845. https://doi.org/10.1086/670335

Nuijten RJM, Kolzsch A, van Gils JA et al (2014) The exception to the rule: retreating ice front makes Bewick's Swans Cygnus columbianus bewickii migrate slower in spring than in autumn. J Avian Biol 45:113-122. https://doi.org/10.1111/j.1600048X.2013.00287.x

Oakeson BB (1954) The Gambel's sparrow at Mountain Village, Alaska. Auk 71:351-365

Pielou EC (1994) A naturalist's guide to the Arctic. University of Chicago Press, Chicago

Piersma T, Drent J (2003) Phenotypic flexibility and the evolution of organismal design. Trends Ecol Evol 18:228-233. https://doi. org/10.1016/S0169-5347(03)00036-3

Pulido F, Berthold P (2004) Microevolution response to climate change. Adv Ecol Res 35:151

Rakhimberdiev E, Winkler DW, Bridge E et al (2015) A hidden Markov model for reconstructing animal paths from solar geolocation loggers using templates for light intensity. Mov Ecol 3:1-15. https:// doi.org/10.1186/s40462-015-0062-5

Rakhimberdiev E, Saveliev A, Piersma T, Karagicheva J (2017) FLight $\mathrm{R}$ : an R package for reconstructing animal paths from solar geolocation loggers. Methods Ecol Evol 8:1482-1487. https://doi. org/10.1111/2041-210X.12765

Robinson DE, Estilo TV, Program NCDR (2012) NOAA climate data record (CDR) of Northern Hemisphere $(\mathrm{NH})$ snow cover extent (SCE). https://catalog.data.gov/dataset/noaa-climate-data-recor d-cdr-of-northern-hemisphere-nh-snow-cover-extent-sce-versi on-1

Schmaljohann H, Naef-Daenzer B (2011) Body condition and wind support initiate the shift of migratory direction and timing of nocturnal departure in a songbird. J Anim Ecol 80:1115-1122. https ://doi.org/10.1111/j.1365-2656.2011.01867.x

Schmaljohann H, Lisovski S, Bairlein F (2017) Flexible reaction norms to environmental variables along the migration route and the significance of stopover duration for total speed of migration in a songbird migrant. Front Zool 14:17

Seavy NE, Humple DL, Cormier RL, Gardali T (2012) Establishing the breeding provenance of a temperate-wintering North American passerine, the Golden-crowned Sparrow, using light-level geolocation. PLoS One. https://doi.org/10.1371/journal.pone.0034886

Smith RJ, Moore FR (2005) Arrival timing and seasonal reproductive performance in a long-distance migratory landbird. Behav Ecol Sociobiol 57:231-239. https://doi.org/10.1007/s0026 5-004-0855-9

Team RDC (2014) R: a language and environment for statistical computing. R Foundation for Statistical Computing, Vienna. https:// www.gbif.org/en/tool/81287/r-a-language-and-environment-forstatistical-computing

Terrill SB (1987) Social dominance and migratory restlessness in the dark-eyed junco, Junco hyemalis. Behav Ecol Sociobiol 21(1):1-11

Terrill SB, Ohmart RD (1984) Facultatie extension of fall migration by Yellow-rumped Warblers (Dendroica coronata). Auk 101:427-438

Tottrup AP, Thorup K, Rainio K et al (2008) Avian migrants adjust migration in response to environmental conditions en route. Biol Lett 4:685-688

Turbek SP, Scordato ESC, Safran RJ (2018) The role of seasonal migration in population divergence and reproductive isolation. Trends Ecol Evol 33:164-175. https://doi.org/10.1016/j.tree.2017.11.008

Wassenaar LI, Hobson KA (2003) Comparative equilibration and online technique for determination of non-exchangeable hydrogen of keratins for use in animal migration studies. Isot Environ Health Stud 39:1-7

Wassenaar L, Hobson K (2006) Stable-hydrogen isotope heterogeneity in keratinous materials: mass spectrometry and migratory wildlife tissue subsampling strategies. Rapid Commun Mass Spectrom 20:2505-2510. https://doi.org/10.1002/rcm.2626

Winger BM, Barker FK, Ree RH (2014) Temperate origins of long-distance seasonal migration in New World songbirds. Proc Natl Acad Sci USA 111:12115-12120. https://doi.org/10.1073/pnas.14050 00111

Wingfield JC, Meddle SL, Moore IT, Busch S, Wacker D, Lynn S, Clark A, Vasquez RA, Addis E (2007) Endocrine responsiveness to social challenges in northern and southern hemisphere populations of Zonotrichia. J Ornithol 148(suppl.):S435-S441

Winkler DW, Gandoy FA, Areta JI et al (2017) Long-distance range expansion and rapid adjustment of migration in a newly established population of Barn Swallows breeding in Argentina. Curr Biol 27:1080-1084

Yeh PJ, Price TD (2004) Adaptive phenotypic plasticity and the successful colonization of a novel environment. Am Nat 164:531-542

Publisher's Note Springer Nature remains neutral with regard to jurisdictional claims in published maps and institutional affiliations. 